\title{
Why Are They So Afraid of Children's Books? The Subversive Power of Imagination (Part 1) ${ }^{1}$
}

\section{Abstract:}

The article discusses the subversive power of children's books as it is expressed in many classical and contemporary works for young readers. Starting with a brief psychological explanation of the source of creativity and playfulness in children's literature, the author uses a Bakhtinian approach in analysing the carnivalesque quality of these books in their ability to create a topsy-turvy world, to use 'a festive laughter,' to present grotesque bodily transformations, and to discuss the lower stratum bodily functions such as food consumption and excretion. Many adults often underestimate the power of children's literature, and at the same time, some books are considered dangerous; therefore, they need to be protected from various attempts to censor or to ban them as unappropriated for children.

\section{Key words:}

banned books, carnivalesque, censorship, children's and young adult literature, Mikhail Bakhtin, subversiveness

\section{Skąd taki lęk przed książkami dla dzieci? Wywrotowa moc wyobraźni (część 1)}

\section{Abstrakt:}

W artykule omówiono wywrotową moc książek dla dzieci, wyrażoną w wielu klasycznych i współczesnych utworach dla młodych odbiorców. Wychodząc od krótkiego psychologicznego wyjaśnienia źródła kreatywności i żartobliwości

* Olga Bukhina - MA, is a translator, writer, and independent scholar. Her research interests include American and Russian children's literature, the images of orphans and death in children's books, and the history of translation of children's literature. contact: bukhina.olga@gmail.com.

1 I would like to thank the members of SOFPHIA (Socialist and Feminist Philosophers Association) and particularly Margaret McLaren and Karsten J. Struhl for their helpful comments and fruitful discussion on the earlier version of this text and its second part. 
w literaturze dziecięcej, autorka wykorzystuje Bachtinowskie podejście w analizie karnawałowego wymiaru tych książek - ich zdolności do kreowania świata na opak, używania „świątecznego śmiechu”, przedstawiania groteskowych przemian cielesnych i ukazywania takich funkcji dolnych partii ciała, jak jedzenie i wydalanie. Wielu dorosłych często nie docenia siły literatury dziecięcej, a jednocześnie niektóre książki są uważane za niebezpieczne; dlatego należy je chronić przed różnymi próbami cenzurowania lub zakazywania ich jako nieodpowiednich dla dzieci.

\section{Słowa kluczowe:}

zakazane książki, karnawalizacja, cenzura, literatura dziecięca i młodzieżowa, Michał Bachtin, subwersywność

\section{[...] art subverts dominant consciousness, the ordinary experience.}

- Herbert Marcuse, The Aesthetic Dimension Toward a Critique

of Marxist Aesthetics

\section{Introduction: Children's Books and Imagination}

$A$ contemporary Russian children's author and publisher Artur Givargizov they are written by adults who are learning, and not teaching. In truth, almost all children's books are written by adults, but they are written by very special adults, those with vivid imagination and ability to see the world through the child's eyes. Many books possess a hidden subversive power that helps the next generations to change the world. In many cases and many countries, authorities and governments, conservatives of all sorts, and parents and educators who are not ready to embark on the journey to an adventure with a child feel threatened by these books. Children are too often conveniently seen as passive recipients of adults' craftsmanship and educational approaches, and many books aim to maintain the status quo and to support the existing, often political or cultural, repressive order. The books with subversive power promote a wild 'childish' imagination that is very similar to the imagination of children, while many other books might reveal the hidden adult political and cultural agendas aimed at influencing certain types of behaviour and 'advising' children on how to live their lives. Often, the difference is clear; however, it is very important to remember that the 'pure' cases - pure didactic or pure subversive - are relatively rare. Some books exemplify one or another category, but in many cases, we see these tendencies mixed and intertwined. Using the various examples of 
British, American, and European titles, from picture books to young adult novels, I will demonstrate the intrinsic subversive power of playful and imaginative children's literature. As an American scholar, Alison Lurie (1998), who was one of the first to speak about the subversiveness of children's literature, states:

Most of the great works of juvenile literature are subversive in one way or another: they express ideas and emotions not generally approved of or even recognized at the time; they make fun of honored figures and piously held beliefs; and they view social pretenses with clear-eye directness, remarking - as in Andersen's famous tale - that the emperor has no clothes (p. 4).

Every person growing up in the contemporary society is, to some degree, exposed to children's and teens' books, at least in the frame of school education, if not through the family. The power of children's literature is often underestimated, and at the same time, it is often seen as dangerous and one that needs to be controlled. Children are understandably sensitive to a didactic or moralistic tone, and they do not respond to it very well, even though historically the first books for children were either primers and other educational materials, or didactic and religious texts. The beginning of the modern children's literature is traditionally marked by A Little Pretty Pocket-Book, Intended for the Instruction and Amusement of Little Master Tommy, and Pretty Miss Polly with Two Letters from Jack the Giant-Killer written by a British publisher John Newbery (1744/2009; republished in Colonial America in 1762). A little bit later, in the earlier part of the $19^{\text {th }}$ century, with Hans Christian Andersen's fairy tales, which were not directly based on folklore like Charles Perrault's and Brothers Grimm's adaptations, children's literature clearly separated itself from literature for adults. ${ }^{2}$ Since its inception, children's literature aimed for different sets of opposing goals - to entertain and to educate, to evoke imagination and to teach children the rules. Most of what was written in almost three centuries of children's literature shows us a mixture of these tendencies.

Before discussing particular books, it is important to look at the psychological qualities of the authors who are writing for children and to see the sources of their inspiration. A children's writer, from the very best to the mediocre, wants to be in touch with the imaginative power of children and their ability to put together things that cannot be together in reality. Children's books often contain

2 It is not a coincidence that the highest American prize for achievements in children's literature is the Newbery Medal, and the highest children's literature international prize is the Hans Christian Andersen Award. 
what does not exist in 'normal' (known, ordinary, and adult) experience. Little girls normally do not fall into rabbit's holes, and white rabbits normally do not wear pocket watches. At the same time, as I have already mentioned, not all children's books are based on imagination; some of them clearly pursue educational and didactic purposes. Psychologically, two paradigms may illustrate, if not completely explain, the source of writers' imagination. On the one hand, it will be useful to look at Sigmund Freud's theory of id, ego, and superego. The place from where a children's writer 'extracts' these child-like and unruly fantasies is surely connected to this "dark, inaccessible part of our personality," as Freud (1933/1990, p. 91) describes the id. On the contrary, the didactic literature that is produced to keep the status quo and an existing order originates in superego, a parental agency. To further illustrate the interplay between the imaginative and the moralistic, we also may use a much simpler construction suggested by an American psychiatrist Eric Berne, the creator of transactional analysis. He described the interpersonal relationships using three ego states of the individuals which, in some sense, correspond with Freudian id, ego, and superego. Berne calls these states Child, Adult, and Parent. For him, creativity and playfulness come from the Child who is much less dark and mysterious than the id. Berne (1964) suggests that "every individual was once younger than he is now and that he carries within him fixated relics from earlier years which will be activated under certain circumstances" (p. 24). The moralistic attitude comes from the Parent because "every individual has had parents (or substitute parents) and [...] he carries within him a set of ego states that reproduce the ego state of these parents (as he perceived them), and [...] these parental ego states can be activated under certain circumstances" (p. 24). Many writers instinctively talk about their inner child as a place from where their ideas for children's books come. Moreover, "[t]he natural Child is a spontaneous expression: rebellion or creativity" (p. 26). Or both. These who produced the best examples of children's literature, like Lewis Carroll, J. M. Barrie, or C. S. Lewis, reportedly, were the grown-ups who never grew up. The image of Barrie's Peter Pan is often used as a symbol of a forever young children's literature.

So, Peter and Wendy (Barrie, 1911), based on the author's play (Barrie, Boucicault, \& Frohman, 1904), will be my first, and the most obvious, example of the subversive power of children's books. Lurie (1998) compares the play with classical pantomimes with their "songs and dances, fights and flights," and notes that "Peter Pan presents a medley of incoherent fantasy settings - mermaids' lagoon, the forest full of wolfs and Indians, the pirate ship" (pp. 126-127). All these fantastic and dangerous settings are intimately connected not only to the creative Child of the writer but also to the dark depths of id where all wishes, without any limitations, come true. The dreamlike quality 
of Peter Pan and its unlimited fantasy help children not to get too engrossed into the boring reality of the adult world. At least, not to do it too soon. The premise of the book is to break all the norms of parent-children relationships. "It demonstrates graphically that parents are timid and hypocritical and that it is far better to be young and live in Never-Never Land" (p. 131). This attitude allows childhood to go beyond its temporary limits, and it resonates not only with children, but also with adults whose inner Child stays active. This is a general quality of children's books with subversive power; they are often read or reread by adults. That was very clearly demonstrated in the phenomenon of 'Pottermania' that captured so many kids as well as adults. J. R. R. Tolkien (1964) in his essay Tree and leaf claims: "If a fairy story is a kind worth reading at all it is worthy to be written for and read by adults. They will, of course, put more in and get more out than children can" (p. 43). Rereading children's books many years later may be real fun, or as a late fantasy writer Ursula K. Le Guin (2009) put it, "Revisiting a book loved in childhood may be principally an act of nostalgia [...] [however] you may well discover a book far less simple and unambiguous than the one you remembered. That shift and deepening of meaning can be a revelation both about the book and yourself" (p. 20). Adults may feel this refreshing power of children's books again and again exactly because they are deepening their rejuvenating qualities. Contemporary literary studies use the term 'crossover literature' to describe the books that are equally attractive to children/teens and to adults. In these cases, both kids and adults are the "dual audience" (Beckett, 2011, pp. 58-61) of these books.

Such books often reveal a clash between children protagonists and adult characters. A famous British writer, P. L. Travers (1934), shows the sharp contrast between childhood and adulthood: in her Mary Poppins, it becomes a dreamlike childhood versus the boring bank manager's existence. In this book, the unlimited fantasy offers children an otherworldly experience. It is very important to mention that one of the adults there is quite unusual. With her huge umbrella, Mary Poppins travels by air with the wind. She, it seems, is on the children's side. Mary Poppins breaks the whole image of a nanny as someone boring, stable, and grounded. She mixes everything up and changes the appropriate order of things. From the very beginning of British children's literature to the present (from Lewis Carroll to J. K. Rowling), the elements of an imaginative, anarchic, upside-down world that does not obey the usual 'adult' rules may be found. Often, these anarchic and liberating tendencies are expressed through the image of an orphan. The relationships with parents (or a lack of parents) are one of the most important pivots of many children's books. The theme of an orphan in a children's book possesses a particular subversive 
power. An orphan in the book is capable of coping with life without the help of parents, without their constant control and instructions. (Isn't it a dream of every child?). 'No parents' means no shell within which to hide. At the same time, 'no parents' means much more freedom, and dangerous and exciting adventures. Being an orphan also means being special, a lost or stolen child of the King, Tsar, or a rich or famous parent. ${ }^{3}$ An orphan in the book is not only a pitiful creature who constantly needs somebody's help; more and more often, she or he is a true hero, a saviour of the world (the world as a whole, or some small part of the world around her or him), and it can be done without any help of adults (Griswold, 1992, p. 4). Instead, in order to be saved, the adults often rely on children and teens. The quintessential example here is Harry Potter, but before him and after him, we see plenty of mythological and books' characters, girls and boys, who were performing the same function (Saxena, 2012, p. 36), and we will talk about some of them later. This is the explosive truth of children's literature - adults are not that necessary. We need, of course, to understand and to remember that this is not a message to get rid of all parents, even though little Max from Maurice Sendak's (1963/2012) Where the Wild Things Are, as we see later, wants to literally eat his mom, and the title character of Roald Dahl's (1988) Matilda is doing everything to get rid of her awful parents and her cruel school headmistress. Nevertheless, it is a message for the future be brave, independent, and capable of your own decision making.

\section{Carnival in Its Children's Incarnation}

"Educators, historians, and fanatics have long used children's books to pass along national myths and values - a hallowed if not always honorable tradition" (Handy, 2017, p. 183). The story of George Washington who could not tell a lie to his father is as didactic and false as the story of Lenin who, when he was a boy, always would tell the truth even at the risk of losing a good grade. (Nobody, probably, would claim that these two never said a lie as adult politicians.) The hagiographic (stories of saints) style has been popular in children's literature for a very long time, but it is not what children like to read. Fortunately, enough children's authors are writing very differently. Without a conscious plan of raising those who would be able to change the world, children's writers are able to help the new generations to do exactly that. Writing from their inner

3 For more details on why the stories of orphans in children's books are so universal and important one may read my book (Bukhina, 2016). 
child, they join hands with children in embracing unlimited fantasy. Travelling to the world of a talking Scarecrow and a walking Tin Woodman in the wonderful Land of $\mathrm{Oz}$, the American children's literature tradition, like the British children's literature tradition before it, was able to lift itself from the Kansas's humdrum of life to the excitement of the carnival.

Mikhail Bakhtin (1965/2009) introduced the importance of carnival culture in human history and also in literature in his most famous work, Rabelais and His World. In contemporary literary studies, hardly anything can be discussed without the Bakhtinian approach. Some scholars (first of all, Maria Nikolajeva, 2010/2012a) started expanding the theory of carnival culture into the analysis of books for young readers. Children's literature is a quintessential carnival culture with its animal characters talking and being dressed like people (Peter Rabbit of Beatrix Potter, 1902, or Brer Rabbit of Joel Chandler Harris, 1880), with its ability to move from one realm to another (the Land of Oz of L. Frank Baum, 1900, or Narnia of C. S. Lewis, 1950-1956), and with its possibility for a child to become a king for a day (just like a fool during the carnival becomes a king). The concept of 'carnivalesque' gets especially handy in children's literature, as Nikolajeva (2010/2012a) shows in her book Power, Voice and Subjectivity in Literature for Young Readers. She claims that "children's literature scholarship successfully employed and developed Bakhtin's concepts of the carnival and intertextuality, heteroglossia and subjectivity, passage from epic hero towards modern character" (p. 4). Using some of Bakhtin's concepts, I will discuss in more details the carnival as the moment in life when everything is upside-down. Children's books are also able to turn the world inside out: it is a topsy-turvy world where the Cow easily jumps over the Moon, children take care of their parents, and a child alone saves the world. According to Nikolajeva, "carnival, reversing the existing order, elevates the fictional child to a position superior to adults" (p. 42). First of all, it is necessary to get rid of adults' rules. In European children's literature, a classic example of a child who does not obey the rules of adults is Pippi Longstocking, a title character of the book by a famous Swedish author Astrid Lindgren (1945/1988). Alone in the big house, with her horse and a bag of golden coins, Pippi does what she pleases: stands on her head and eats candies instead of boring, prescribed by adults, food. She is in the state of a perpetual carnival, and she gets other children into it. Children's books imply a notion of carnival as a unique space where the laws of ordinary life do not apply. What is available to adults only during the exceptional, specially carved out time of carnival, children may have every night while reading the book. Just as during the carnival, when a spectator does not differentiate himself/herself from a performer, children often do 
not differentiate themselves from a character in the book. This is a designated time when a person (a child) can feel free of any oppression and violence. The carnival violence is a play, a game. "[C]arnival celebrated temporary liberation from the prevailing truth and from the established order"; it is a kingdom of "a festive laughter" (Bakhtin, 1965/2009, pp. 10-11). During the carnival, it is possible to make fun of everything, to laugh at anyone. Children's humour also often lacks any reverence towards those who are supposed to be the authorities. Carnival is restricted to a particular time and to a particular space - e.g. a city square; it cannot spread itself to the entire life of the society. The carnival of a children's book is also restricted, trapped inside the pages. It is a protected place; nobody can be punished for what is done during the carnival. Carnival provides equality and intimacy. Children's literature is also a protected place, a safe space where a child can learn about the horrors of the world without experiencing them. Scary books are read in the safety of the bedroom, under a warm blanket, with the loving parent nearby. Nevertheless, the 'lesson' they teach is the lesson of bravery and disobedience. Carnival requires a jester or a trickster who is the true soul of the entire enterprise. The protagonist of a children's book is often that trickster, an agent-provocateur, a prankster. We all remember Tom Sawyer who combines the possibility of being free and out of control as an orphan and the possibility of protesting against the norms of the society as a rascal. Carnival provides some sort of an alibi allowing the child to do what cannot be done during the 'regular hours,' and not to be charged for that. ${ }^{4}$ These books allow this alibi also to their creators, the writers. Children's books, like imaginary friends, allow children (and writers) to get away with what they cannot get away with in real life. A simple example here will be the most famous book of Dr. Seuss (1957/1985; a pen name of Theodor Seuss Geisel), The Cat in the Hat, where the Cat barges in on children when their mother is absent and, with the help of "Thing One" and "Thing Two," he turns the entire apartment upside-down creating a topsy-turvy world of chaos and confusion. "And this mess is so big / And so deep and so tall, / We cannot pick it up. / There is no way at all!" (Seuss, 1957/1985, p. 55). Dr. Seuss truly believed, in his own words, that children "want fun. They want play. They want nonsense" (Handy, 2017, p. 109).

One of the clearest examples of the books where all rules, if not broken for good, are at least suspended for the time being is Sendak's (1963/2012) picture book Where the Wild Thing Are. "Picture books [...] are well suited to

4 I am grateful for this thought to a Russian scholar Ilya Kukulin. 
accommodating elements of fantasy and satirical subversion, which show the influences of the cultural and artistic developments of postmodernity and ontological experimentation" (Mallan, 2012, p. 71). Sendak's story is very simple. Max, dressed in a wolf costume, creates a lot of mischief. His mother is unhappy with him; she calls him the "Wild Thing" (Sendak, 1963/2012, p. 5) and sends him to bed without supper. He threatens to eat her up. Right out of his bedroom, he gets to the island where the Wild Things live. He "tames them with the magic trick of staring into all their yellow eyes without blinking" (pp. 19-20) and becomes their little king. Bruce Handy (2017), the author of Wild Things: The Joy of Reading Children's Literature as an Adult, describes Sendak's book as a "psychologically astute parable about a child learning that anger, while sometimes overwhelming and scary, can be safely expressed and conquered" (p. 61). Handy admits that it is his 'adult' reading and that children might see something else in the book (or even do not like it much). The Wild Things are clearly all subconscious desires and unfulfilled wishes of a small child who wants more freedom to play and to fantasise without restrictions. Max bosses the Wild Things around (very much the way his mother bosses him) and sends them to bed without supper. The island with the Wild Things is a pretty scary place, and Max's relationships with the creatures who are much bigger than him are not without conflicts. The Wild Things have their doubts about whether he is really the king. They might even eat him up (they do not). When this wild lifestyle stops being a novelty, Max says his farewells and returns in a little boat back to his home. His supper waits for him, and it is still hot. The Wild Things may be interpreted in many ways, but first of all, it is an empowering experience when a child is able to conquer his/her fears and his/her anger and becomes a master of his/her own desires. Reading this book, a child is able to open himself/herself to a new experience of freedom and disobedience (even though the adult reader understands that it is all a dream or a fantasy, and the entire Max's adventure did take less time than he needs for his food to cool down). At the same time, it is clear that freedom comes at the price of insecurity. It is still a picture book, and in the end, Max presumably is completely safe in his mom's arms, but it gives the reader a taste of being outside of a comfort zone. Sendak is both an author and an illustrator of the book, and the imagery of it is very important. The Wild Things of Max's unconsciousness are sufficiently scary and much bigger than Max. They are not lacking in razor-edged teeth, sharp horns, and strong hoofs. Max stays in his wolf costume through the entire adventure, and he looks like a small animal which is again an element of the carnival and masquerade. The bodies of the Wild Things are grotesque. The grotesque body is another important Bakhtinian 
(1965/2009) concept. "The grotesque body [...] is a body in the art of becoming. It is never finished, never completed; it is continually built, created, and builds and creates another body. Moreover, the body swallows the world and is itself swallowed by the world" (p. 317). Max wants to eat his mom, one of the Wild Things wants to eat Max; in the movie based on the book, another Wild Thing is swallowing Max to keep him safe. ${ }^{5}$ Who is gobbling up whom in these carnivalesque moments that are completely subverting the proper order where children have their dinners and go straight to bed? 6

The subversive power is hidden not only in the picture books. One of the main reasons for the worldwide success of the Harry Potter seven volumes (Rowling, 1997-2007) is the notion that a child has its own power, that the salvation cannot come from adults, but needs to come from children; therefore, they are the future that is destined to change the world. Harry Potter himself has a combination of various characteristics all of which are necessary for the ideal protagonist of a children's book. He is an orphan, he is marked as a very special one, and he is a saviour who almost dies for the sake of the others. But he is not fighting the Evil alone. Importantly, there is a whole group of children, his friends Ron and Hermione and many others, who are involved in this brutal battle between the Good and the Evil. I will not be retelling the details of this long contemporary children's saga as well as an ample scholarship around it; I just want to mark a couple of important moments of hidden or not-so-hidden resistance to the world of adults in the books. First of all, there are the school rules and regulations that often need to be bent or broken by Harry in order to succeed in chasing Lord Voldemort and his allies. Second, Harry's fight is not only against He-Who-Must-Not-Be-Named, but also against the authorities that rule the wizards' world, and not only because the Ministry of Magic is, at some point, fully under the influence of Lord Voldemort. Again, Harry and his friends carry out their struggles against the Ministry with very little help from adults. Of course, as in many other children's books, there are some adults who are on the kids' side and act as "magic helpers," in the terminology suggested by Vladimir Propp (1928/1968). He analyses the basic structural components of folk tales and suggests that in folklore "the hero is the person who is supplied with a magical agent (a magical helper), and who makes use

5 In contemporary American culture, not less known than the book written in the 1960s is the movie with the same name directed by Spike Jonze (2009).

6 Many more examples of inappropriate eating and its subversive potential in children's books may be found in Carolyn Daniel's (2006) Voracious Children: Who Eats Whom in Children's Literature. 
of it or is served by it" (p. 50). Mary Poppins, Glinda, the Good Witch of the South, and Professor Albus Dumbledore, the headmaster of Hogwarts School of Witchcraft and Wizardry, are among these "magic helpers." Of course, even such a magic helper may still be "arrogant and conceited, repeatedly reminding the children of her [or his] own superiority, not merely because of her [or his] magic abilities but in the first place as an adult" (Nikolajeva, 2012b, p. 52). In any case, the subversive actions in contemporary books more likely would come from a child diminishing the role of the helper who might even die at the end of the book like Professor Dumbledore. It is important to notice that right after the publication of the Harry Potter heptalogy many writers immediately started to write something similarly powerful with the girls as the lead characters. These books are written in different genres: historical novels, fantasy, or dystopias. A few examples of such strong female characters are Calpurnia of The Evolution of Calpurnia Tate by Jacqueline Kelly (2009), Frances Hardinge's (2015) Faith of The Lie Tree, Katniss of the Hunger Games trilogy by Suzanne Collins (2008-2010), Tris of the Divergent series by Veronica Roth (2011-2013). ${ }^{7}$ It is not that before Harry Potter children's literature knew only boys; Roald Dahl's (1988) Matilda and Philip Pullman's $(1995,1997,2000)$ Lyra clearly predate Harry, but after the appearance of 'The Boy Who Lived,' it became even more obvious how important it is to bring in female protagonists with the same ability to disobey the rules of the society, whatever this society is - magical, post-apocalyptic, capitalist, socialist, or post-Soviet.

\section{Bakhtinian Bodily Lower Stratum}

All contemporary societies are not very comfortable with bodily functions in children's books. A part of the debate about what is appropriate for children and what is not concerns precisely these bodily functions, first of all, sex and excretions. For quite a long time, urination and defecation, together with anything connected to sex, were taboos in children's literature. Until comparatively recent times, mentioning various bodily discharges, for example menstruation, was 'not appropriate' for the American children's books. Judy Blume's (1970) Are You There God? It's Me, Margaret, with its discussions of the first period, sanitary napkins, and bras, actually pioneered the topic, and for a long time, many librarians did not recommend the book for this very

7 Lyra Belacqua of His Dark Materials trilogy by Philip Pullman $(1995,1997,2000)$ is the most important girl-predecessor of Harry Potter. 
reason. In the American Library Association's (1996-2019) 100 Most Frequently Challenged Books: 1990-1999, it is listed under \#60. ${ }^{8}$ A carnival, as Bakhtin describes it, is heavily connected to the bodily functions. He uses the concept of a grotesque body to explore the bodily freedom of the carnival. It stresses the importance of the body, and children, especially small children, are in the period of their lives when they are just starting to understand bodily functions. Bakhtin (1965/2009) states that "the essential role belongs to these parts of grotesque body in which it outgrows its own self, transgressing its own body, in which it conceives a new, second body: the bowels and the phallus" (p. 317). The grotesque bodily transformations are not a rarity in children's books, and the phallus may easily be substituted by other extremities. Alice in Lewis Carroll's (1865) Alice's Adventures in Wonderland goes through the drastic changes of her body, from normal, to very small, to gigantic, to normal again. Her neck grows enormously long, and she is mistaken by a dove for a snake, with all possible phallic associations there. Alice is actually transformed into a giant carnival figure on stilts. This is a clear image of the grotesque body as it is seen by children and by children's books' writers. Children's literature does not lack giants, dwarfs, gnomes, fauns, and other kinds of human-like creatures whose bodies are human and non-human at the same time. Sometimes, they are the animal-looking monsters like strange, frightening creatures in Sendak's (1963/2012) Where the Wild Thing Are, or the Gruffalo invented by a little scary Mouse in Julia Donaldson's (1999/2005) picture book The Gruffalo. This Gruffalo is "a creature with terrible claws and terrible teeth in his terrible jaws" (p. 2). The Mouse invents it to protect himself from other animals and later discovers that this amazing and frightening monster does exist. But, of course, the sly Mouse, a carnival trickster, is able to fool this dangerous creature.

Another important function of the body and an important part of a carnival is food consumption. "Eating and drinking are one of the most significant manifestations of the grotesque body," and in the act of eating, "the body transgresses [...] its own limits: it swallows, devours, rends the world apart, is enriched and grows at the world's expense" (Bakhtin, 1965/2009, p. 281). Bakhtin illustrates it with multiple examples from the $16^{\text {th }}$-century François Rabelais's five volumes about the life of two giants, Gargantua and his son Pantagruel. The food consumption (without heavy drinking, of course) is very important in children's books. From 'more porridge please' of Dickens's Oliver Twist to an

8 A few more books I discussed in this article also made it to the list: Mark Twain's (1884) Adventures of Huckleberry Finn (\#5), Lois Lowry's (1992) The Giver (\#11), J. K. Rowling's (1997-2007) Harry Potter series (\#48). 
abundance of the dishes at the Harry Potter Hogwarts' feasts, children's books are full of the vitality of eating. In this sense, they are truly Rabelaisian. One of such quintessential food moments is an enormous menu of a reconciliation feast from the book of a famous British writer Elizabeth Goudge (1946/2001), The Little White Horse (a favourite children's book of J. K. Rowling): "Plum cake. Saffron cake. Cherry cake. Iced fairy cake. Éclairs. Ginger-bread. Meringues. Syllabub. Almond fingers. Rock cakes. Chocolate drops. Parkin. Cream horns. Devonshire splits. Cornish pastry. Jam sandwiches. Lemon-curd sandwiches. Lettuce sandwiches. Cinnamon toasts. Honey toast" (pp. 221-222). Harry Potter's childhood food deprivation at the house of his Muggle relatives changes into the vast festivities of the Wizards' school. An abundance of food in Hogwarts truly empowers Harry. All eight movies based on these seven books dwell on school feasts as long as possible. Food and drinks symbolise the victory; in the very last movie as soon as the ultimate victory in the battle of Good and Evil is achieved, everyone who is still alive gets some hot and clearly tasty drink. This is a children's version of the Bakhtin's (1965/2009) notion of an "utopian realm of community, freedom, equality, and abundance" (p. 9).

It is clear from Rabelais's books (and not only) that if you eat and drink, you need to relieve yourself. "Eating, drinking, defecation and other elimination (sweating, blowing the nose, sneezing), as well as copulation, pregnancy, dismemberment, swallowing up by another body [like in Where the Wild Thing Are - all these acts are performed on the confines of the body and the outer world, or on the confines of the old and new body" (Bakhtin, 1965/2009, p. 317). Up to some point, with plenty of food in children's books, the opposite processes were not a part of it. In one of the long forgotten books, The Boy Tar, by a British writer Thomas Mayne Reid (1852), a boy spends weeks and weeks in a ship's hold. The reader knows all details of what he ate and drank during that time, but nothing about him going to the bathroom. For more than a century, children's literature kept avoiding the scatological topics leaving them mostly to children's folklore and sophomore jokes. Only very recently, the 'confines' of the body were drastically extended in children's literature. Firstly, an endless number of potty-training books, both didactic and instructional, came into the American and European children's consumption. That was not a very radical step because these books serve not children's, but parents' needs. The next step was more innovative and imaginative; what earlier existed only in children's folklore radically entered the 'legitimate' children's literature. One of the striking examples of allowing children a freedom of talking about what they really want to talk about is a picture book The Story of the Little Mole Who Went in Search of Whodunit by Werner Holzwarth and Wolf Erlbruch (1989/2007), published originally in 
Germany. A mole who is just getting out of his hole gets pooped on his head by some unknown animal; after that, the mole is on a mission to discover whom the poop belongs to. A recent Russian book, Alla Belova’s (2018) Vse delaiüt èto [Everyone Does It], with illustrations of Boris Voŭtsekhovskiŭ, talks about a similar and equally exciting topic: human and animal flatus. Now a child-reader can see and almost feel and smell what earlier was only inside the potty. In these books, there are no more of the educational pretences of the potty books; they are truly ground-breaking and carnivalesque.

\section{Conclusion: Who will Speak on Behalf of These Books?}

Those adults who are afraid of the innovations hidden in children's books regularly try to ban and censor them, to take them out of the libraries and from the bookstores' shelves, and in the most extreme cases, to get rid of their authors. It is often done with the implicit or explicit help of the state that prefers its youngsters be 'law abiding' citizens from the crib. We will see in the second part of this article how it was implemented in the Soviet Union. The authorities are quite right to be afraid; children's literature is a very powerful thing. It is dangerous because it may teach children to think for themselves. The striking evidence of the power of the book that provoked dictators to have it banned is The Story of Ferdinand written by Munro Leaf (1936) and illustrated by Robert Lawson. "[T]he story of the daisy-eating bull became the first American picture book to be labeled subversive" (Silvey, 2004, p. 24). It was seen as controversial and pacifist in Spain - by those who supported and by those who confronted Franco (Hearn, 1986), and was banned there until Franco's death. "Adolf Hitler ordered the book burned as 'degenerate democratic propaganda.' In the United States the book was accused of promoting fascism, anarchism, and communism. But along the way, Ferdinand gained some admirers as well - including Thomas Mann, H. G. Wells, Gandhi, and Franklin and Eleanor Roosevelt" (Silvey, 2004, pp. 24-25). So much power had this small book have that many famous people felt the necessity to form an opinion about it. Since both the right and the ability of children's literature to teach independent thinking need to be protected, and children themselves rarely can fight back, it is adults who should fight on children's behalf. As we have already seen, groups such as the American Library Association are compiling lists of books that had already been prohibited or non-recommended to expose the absurdity of such prohibitions. This makes the lists public and brings these books back to readers; and so, adults may speak on behalf of the banned children's books. 
Nevertheless, it is very important to remember that the subversive tendencies are historically bound. What was on the frontier of subversive literature in the $19^{\text {th }}$ century now is seen as catering to the views already accepted as obsolete, as least in some aspects, for example, the attitude toward Native Americans in Mark Twain's (1876) Adventures of Tom Sawyer as it is seen in portraying the 'bad guy,' Injun Joe. Moreover, after so many years, some books might have lost their subversive power: what was ground-breaking and disturbing then is now widely acceptable and loved by conservatives. The 'mistakes' of the past are also 'teaching' the reader to not trust the book entirely and to not whitewash the past, and at the same time, to not judge the book written a hundred year ago according to the contemporary understandings. ${ }^{9}$ The books may also gain an extra subversive power when they enter into a different culture. C. S. Lewis's The Chronicles of Narnia hardly would be seen as subversive in England in the 1970s but translated into Russian and circulated in Samizdat in the 1980s in Russia, they became truly revolutionary. Narnia stories spoke about religious beliefs that were not approved by the Soviet state, and any mentioning of Christianity would be censored in the children's book. ${ }^{10}$

A psychological explanation of the source of creativity and playfulness in children's books helps us to see where the subversive power of children's literature is coming from. Through the Bakhtinian approach to literary analysis, we understand how the carnival enters the space of children's books and brings in the freedom to discuss the body and its functions. Children's books create a topsy-turvy world where the child is powerful and independent, and many British and American classics were able to keep their subversive nature through generations of young readers. In the second part of the article, we will examine particular examples of American, Soviet, and Russian children's books that were seen as subversive and dangerous in various periods in the history of the USA, the Soviet Union, and Russia.

9 The scandal around the 'new' edition of Mark Twain's Adventures of Tom Sawyer and Huckleberry Finn: The NewSouth Edition (Gribben, 2011) with offensive racial epithets 'cleaned-up' from the books shows how contemporary 'sensibilities' could stir up the controversy and smear the honest anti-racist stand of the author (Messent, 2011).

10 In the Soviet Union, Samizdat (literally, self-publishing) reproduced censored or prohibited books in a few copies that were passed from reader to reader. Only one book out of seven Narnia stories was published in the 1970s in the Soviet Union. By the 1980s, the other six books were introduced to young readers through Samizdat. These self-made typed carbon-copied books circulated widely for almost a decade until it was possible to publish them all in 1991, during perestroika (Bukhina, 2019). 


\section{References}

American Library Association (1996-2019). 100 most frequently challenged books: 1990-1999. Retrieved from http://www.ala.org/advocacy/bbooks/100-mostfrequently-challenged-books-1990-1999.

Bakhtin, M. (2009). Rabelais and his world (H. Iswolsky, trans.). Bloomington, IN: Indiana University Press. (Original work published 1965).

Barrie, J. M. (1911). Peter and Wendy. London: Hodder \& Stoughton.

Barrie, J. M. (Writer), Boucicault, D. (Director), Frohman, C. (Producer). (1904, December 27). Peter Pan, or the boy who would not grow up. Live performance at the Duke of York's Theatre, London.

Baum, L. F. (1900). The wonderful Wizard of Oz. Chicago, IL: George M. Hill Company. Beckett, S. L. (2011). Crossover literature. In P. Nel \& L. Paul (Eds.), Keywords for children's literature (p. 58). New York, NY \& London: New York University Press.

Belova, A. (2018). Vse delaiut èto. Moskva: Samokat.

Berne, E. (1964). Games people play: The psychology of human relationships. New York, NY: Grove Press.

Blume, J. (1970). Are you there God? It's me, Margaret. Englewood Cliffs, NJ: Bradbury Press.

Bukhina, O. (2016). Gadkiŭ Utenok, Garri Potter i drugie. Putevoditel' po detskim knigam o sirotakh. Moskva: KompasGid.

Bukhina, O. (2019, September 25). Russian Samizdat, children's literature, and the sunset years of the Soviet empire. ChLA International Committee Blog. Retrieved from https://childlitassn.wixsite.com/intlcommittee/single-post/2019/09/25/RussianSamizdat-Children's-Literature-and-the-Sunset-Years-of-the-Soviet-Empire.

Carroll, L. (1865). Alice's adventures in Wonderland. London: Macmillan.

Collins, S. (2008). The Hunger Games. New York, NY: Scholastic Press.

Collins, S. (2009). Catching fire. New York, NY: Scholastic Press.

Collins, S. (2010). Mockingjay. New York, NY: Scholastic Press.

Dahl, R. (1988). Matilda. London: Jonathan Cape.

Daniel, C. (2006) Voracious children: Who eats whom in children's literature. New York, NY: Routledge.

Donaldson, J. (2005). The Gruffalo. New York, NY: Dial Books for Young Readers. (Original work published 1999).

Dr. Seuss (1985). The Cat in the Hat. New York, NY: Random House. (Original work published 1957).

Freud, S. (1990). New introductory lectures on psychoanalysis. New York, NY \& London: W. W. Norton. (Original work published 1933).

Givargizov, A. (n.d.). Novaîa detskaîa literatura. Retrieved from https://www.labirint. ru/top/egmont/. 
Goudge, E. (2001). The little white horse. London: Puffin Books. (Original work published 1946).

Gribben, A. (Ed.). (2011). Mark Twain's Adventures of Tom Sawyer and Huckleberry Finn: The NewSouth edition. Montgomery, AL: NewSouth Books.

Griswold, J. (1992). Audacious kids: Coming of age in America's classic children's books. New York, NY \& Oxford: Oxford University Press.

Handy, B. (2017). Wild things: The joy of reading children's literature as an adult. New York, NY: Simon \& Schuster.

Hanks, T., Goetzman, G., Sendak, M., Carls, J., Landay, V. (Producers), \& Jonze, S. (Director). (2009). Where the Wild Things are [Motion picture]. United States: Warner Bros.

Hardinge, F. (2015). The lie tree. London: Macmillan.

Harris, J. C. (1880). Uncle Remus: His songs and his sayings. New York, NY: D. Appleton and Company.

Hearn, M. P. (1986, November 9). Ferdinand the Bull's 50 th Anniversary. The Washington Post. Retrieved from https://www.washingtonpost.com/archive/entertainment/books/1986/11/09/ferdinand-the-bulls-50th-anniversary/3325d6dc-cc684be7-9569-408439896098/.

Holzwarth, W., \& Erlbruch, W. (2007). The story of the little mole who went in search of whodunit. New York, NY: Harry N. Abrams. (Original work published 1989).

Kelly, J. (2009). The evolution of Calpurnia Tate. New York, NY: Henry Holt.

Le Guin, U. K. (2009). Cheek by jowl: Talks and essays on how and why fantasy matters. Seattle, WA: Aqueduct Press.

Leaf, M. (1936). The story of Ferdinand. New York, NY: Viking Press.

Lewis, C. S. (1950). The lion, the witch and the wardrobe. London: Geoffrey Bles.

Lewis, C. S. (1951). Prince Caspian. London: Geoffrey Bles.

Lewis, C. S. (1952). The voyage of the Dawn Treader. London: Geoffrey Bles.

Lewis, C. S. (1953). The silver chair. London: Geoffrey Bles.

Lewis, C. S. (1954). The horse and his boy. London: Geoffrey Bles.

Lewis, C. S. (1955). The magician's nephew. London: The Bodley Head.

Lewis, C. S. (1956). The last battle. London: The Bodley Head.

Lindgren, A. (1988). Pippi Longstocking (F. Lamborn, trans.). London: Puffin Books. (Original work published 1945).

Lowry, L. (1992). The Giver. New York, NY: Houghton Mifflin.

Lurie, A. (1998). Don't tell the grown-ups: The subversive power of children's literature. Boston, MA, New York, NY, Toronto, \& London: Back Bay Book.

Mallan, K. (2012). Strolling through the (post)modern city: Modes of being a flaneur in picture books. The Lion and the Unicorn, 36(1), 56-74.

Mayne Reid, T. (1852). The Boy Tar, or a voyage in the dark. London: Ticknor and Fields. 
Messent, P. (2011, January 5). Censoring Mark Twain's 'n-words' is unacceptable. The Guardian Book Blog. Retrieved from https://www.theguardian.com/books/booksblog/2011/jan/05/censoring-mark-twain-n-word-unacceptable.

Newbery, J. (2009). A little pretty pocket-book. Truru: Dodo. (Original work published 1744).

Nikolajeva, M. (2012a). Power, voice and subjectivity in literature for young readers. New York, NY \& London: Routledge. (Original work published 2010).

Nikolajeva, M. (2012b). The development of children's fantasy. In E. James \& F. Mendlesohn (Eds.), The Cambridge companion to fantasy literature (pp. 50-61). Cambridge: Cambridge University Press.

Potter, B. (1902). The tale of Peter Rabbit. London: Frederick Warne.

Propp, V. (1968). Morphology of the folktale (L. Scott, trans.). Austin, TX: University of Texas Press. (Original work published 1928).

Pullman, P. (1995). Northern lights. London: Scholastic.

Pullman, P. (1997). The subtle knife. London: Scholastic.

Pullman, P. (2000). The amber spyglass. London: Scholastic.

Roth, V. (2011). Divergent. New York, NY: Katherine Tegen Books.

Roth, V. (2012). Insurgent. New York, NY: Katherine Tegen Books.

Roth, V. (2013). Allegiant. New York, NY: Katherine Tegen Books.

Rowling, J. K. (1997). Harry Potter and the Sorcerer's Stone. London: Bloomsbury.

Rowling, J. K. (1998). Harry Potter and the Chamber of Secrets. London: Bloomsbury.

Rowling, J. K. (1999). Harry Potter and the prisoner of Azkaban. London: Bloomsbury.

Rowling, J. K. (2000). Harry Potter and the Goblet of Fire. London: Bloomsbury.

Rowling, J. K. (2003). Harry Potter and the Order of the Phoenix. London: Bloomsbury.

Rowling, J. K. (2005). Harry Potter and the Half-Blood Prince. London: Bloomsbury.

Rowling, J. K. (2007). Harry Potter and the Deathly Hallows. London: Bloomsbury.

Saxena, V. (2012). The subversive Harry Potter: Adolescent rebellion and containment in the J. K. Rowling novels. Jefferson, NC \& London: McFarland.

Sendak, M. (2012). Where the Wild Things are. New York, NY: HarperCollins. (Original work published 1963).

Silvey, A. (2004). 100 best books for children: A parent's guide to making the right choices for your young reader, toddler to preteen. Boston, MA \& New York, NY: A Frances Tenenbaum Book.

Tolkien, J. R. R. (1964). Tree and leaf. London: George Allen and Unwin.

Travers, P. L. (1934). Mary Poppins. London: HarperCollins.

Twain, M. (1876). The adventures of Tom Sawyer. Hartford, CO, Chicago, IL, \& Cincinnati, OH: American Publishing.

Twain, M. (1884). Adventures of Huckleberry Finn. London: Chatto \& Windus. 